\title{
Efficacy of the Aqueous Extracts of Justicia Galeopsis Leaves on the Improvement of Hematological Parameters in Anemic Rats
}

\author{
Ahou L. Loukou ${ }^{1}$, Moussa Gbogbo ${ }^{2}$, Raissa S. Assi ${ }^{1}$, Louise Atchibri-Anin ${ }^{1} \&$ Kouakou Brou ${ }^{1}$ \\ ${ }^{1}$ Food Science and Technology Department, Nangui Abrogoua University, Abidjan, Côte d'Ivoire \\ ${ }^{2}$ Biochemistry Microbiology Department, Jean Lorougnon-Guede University, Daloa, Côte d'Ivoire \\ Correspondence: Ahou L. Loukou, Food Science and Technology Department, Nangui Abrogoua University, \\ Abidjan 02 PO Box 801 Abidjan 02, Côte d'Ivoire. Tel: 225-0773-9990. E-mail: loukouletine@ yahoo.fr
}

Received: June 16, $2020 \quad$ Accepted: July 14, $2020 \quad$ Online Published: July 212020

doi:10.5539/jfr.v9n5p14 URL: https://doi.org/10.5539/jfr.v9n5p14

\begin{abstract}
Antianemc potential of aqueous of Justicia galeopsis leaves was studied using Wistar Albino rats after induction of anemia by phenylhydrazine hydrochloride. Forty rats ( 20 male and 20 female) subdivided into five groups of eight rats were used. There was a group as control (not anemic) and four other anemic groups which had received by gavage respectively $1 \mathrm{ml} / \mathrm{kg}$ of distilled water, $1 \mathrm{ml} / \mathrm{kg}$ of body weight of Vitafer (reference drug commonly used to treat anemia), $100 \mathrm{mg} / \mathrm{kg}$ of body weight of extract of J. galeopsis leaves cooked during 30 $\min$ and $30 \mathrm{mg} / \mathrm{kg}$ of body weight of extract of $J$. galeopsis leaves cooked during $45 \mathrm{~min}$. Hematological parameters (red blood cells, hemoglobin and hematocrit) were analyzed as indices of anemia and the weights of specific organs (liver, spleen and kidney) were evaluated. The results of this investigation had showed that aqueous extract of J. galeopsis leaves cooked improved red blood cells, hemoglobin and hematocrit levels. These extracts were not toxic for liver, spleen and kidney. The administration of $100 \mathrm{mg} / \mathrm{kg} / \mathrm{day}$ of extract of leaves cooked leaves during 30 min promotes a better recovery rate of the number of red blood cells $(94.80 \%)$, hemoglobin level $(159.53 \%)$ and hematocrit $(117.72 \%)$ than Vitafer and the extract of leaves cooked for 45 min. This is suggestive that aqueous extracts of Justicia galeopsis leaves cooked during 30 min may be exploited during 2 weeks in the treatment of anemia.
\end{abstract}

Keywords: galeopsis leaves, water cooking, anemia, hematological parameters

\section{Introduction}

Anemia is a disease that affects all countries in the world, whether industrialized or not (Ponmozhi, \& Ramya, 2015). It is also a public health problem that affects almost a quarter of the world's population. This disease affects people of all ages but the most affected are children, pregnant women and the elderly (Senou et al., 2016). There are many causes of anemia (McLean et al., 2007). The most important causes are nutritional deficiencies, then the pregnancy and the high prevalence of blood parasites such as Plasmodium, Trypanosomes (Sènou et al., 2016). Among nutritional deficiencies, iron deficiency is the main cause of anemia (Ramakrishnan 2002). There is also a deficiency of folic acid and / or vitamin B 12 which causes megaloblastic anemia (Green, 2017).

Some pharmaceutical drugs are used to treat anemia. These include iron, vitamin B12, folic acid etc. The search for other alternatives to overcome the problem of the high cost of pharmaceutical drugs is encouraged by WHO (Sènou et al., 2016). Thus, Justicia secunda leaves (Tossou et al., 2008), Alchornea cordifolia leaves, Coco nucifera milk, Hibiscus sabdarifa flowers (Séguéna et al., 2013), and Jatropha tanjorensis leaves (Idu et al., 2014) were studied and their anti-anemia properties were discovered. Beyond these trees and shrubs, studies have also shown that the consumption of some leafy vegetables, in particular Ipomoea batatas (Osime et al., 2008), Spinacia oleracea (Luka et al., 2014), Moringa olifera (Madukwe et al., 2013) improve hematological parameters. These plants could therefore be used in place of pharmaceutical drugs (Tossou et al., 2008).

Justicia galeopsis is a spontaneous plant whose leaves are eaten as leafy vegetables in Nigeria (Obichi et al., 2015) and Côte d'Ivoire (Kouakou, 2015). In Côte d'Ivoire, the leaves of this plant are very appreciated by populations of Abengourou who like their taste. The cooked dishes of these leaves are offered to distinguished guests or consumed during the festivities (Kouakou, 2015). These leaves contain, in significant quantity, many nutrients in particular iron, vitamin B12, Folic acid, calcium and magnesium (Afolaby et al., 2012; Kouakou, 
2015; Obichi et al., 2015; Loukou et al., 2018).

This plant has advantageous nutritional profile for the health of populations. It could be used like the leaves of Ipomoea batatas, Spinacia oleracea and Moringa olifera in the treatment of anemia. However, it remains little known in the other regions of Côte d'Ivoire. The literature provides information only about their medical uses.

The objective of this study is to test the anti-anemic properties of the aqueous extracts of the leaves of Justicia galeopsis on Wistar rats, after induction of anemia by phenylhydrazine hydrochloride.

\section{Materials and Methods}

\subsection{Collection and Authentication of Plant}

Justicia galeopsis leaves, commonly known in the local language "Agni” as Assiaploua were collected fresh and at maturity from cultivated farmlands located at Abobo. Abobo is one of thirteen communes of the district of Abidjan, Côte d'Ivoire. It is located in Abidjan north between $5^{\circ} 42$ north latitude and $-4^{\circ} 02$ west longitude and at an altitude of 105 meters above sea level (Aka et al., 2013). Plants were identified and authenticated by National Floristic Center (University Felix Houphouët Boigny, Abidjan-Côte d'Ivoire).

\subsection{Processing of Plant}

The fresh leaves were separated from the stem, washed with distilled water and drained at ambient temperature. Collected leaves were divided into three lots. The first lot is that of the fresh leaves obtained by Agbemafle et al. (2012) method and lyophilized. The other two were cooked at $100{ }^{\circ} \mathrm{C}$ respectively during 30 and 45 min by using the method of Randrianatoandro (2010) in the proportion $40 \mathrm{~g}$ of leafy vegetables immerged in $200 \mathrm{~mL}$ of boiled water. Boiled samples were cooled, crushed with a laboratory crusher (Culatti, France) and lyophilized. All lyophilized samples were ground in fine powder and store in a clean dry air-tight bottle in a refrigerator $\left(4{ }^{\circ} \mathrm{C}\right)$ until required for analyses.

\subsection{Preparation of Aqueous Plant Extracts}

Fifty grams of powdered plant material was extracted in 1.51 of distilled water for 24 hours. At the end of extraction time, the mixture was filtered twice through folded cotton and whatman filter grade 1 . The filtrate was evaporated at $50{ }^{\circ} \mathrm{C}$ for 24 hours in a ventilated oven. The dried powder was then stored in containers at $-20{ }^{\circ} \mathrm{C}$ until used for bioassay. The powder obtained was dissolved in distilled water ( $1 \mathrm{ml}$ for $100 \mathrm{~g}$ body weight) and administrated by gavage to rats.

The amount of residue administered to a rat is proportional to the amount of leaves consumed by an adult who weighs about $60 \mathrm{~kg}$.

\subsection{Animal Handling and Grouping}

Eight-week-old male and female Wistar albino rats bred in animal house of higher normal school (E.N.S.) at Felix Houphouet Boigny University were used for this study. The rats weighed on average $127.7 \mathrm{~g}$. The animals were housed in locally fabricated cage. They were allowed to acclimatize to the new environment for seven days before the beginning of the experiment. The rats were fed with animal feed (Ivograin) and water ad libitum. The experimental protocol and the animal handling procedures were conducted according to the guidelines of the ethics committee of Nangui Abrogoua University (Côte d'Ivoire).

\subsection{Experimental Protocol}

Forty Wistar albino rats were used in this study. The rats were randomly divided into five groups made of eight animals (four male and four female) each. Group 1 was not anemic and served as negative control. The rats of other groups were anemic with group 2 as positive control. Groups 3, 4 and 5 were treated with respectively the Vitafer (1 mg/kg of body weight / day (D)), plant extract cooked during $30 \mathrm{~min}$ (100 mg/kg of body weight / day) and plant extract cooked during $45 \mathrm{~min}(30 \mathrm{mg} / \mathrm{kg}$ of body weight / day) from D2 to D15. The plant extract and Vitafer were administered by gavage using a gastric tube. Vitafer is reference drug commonly used to treat anemia.

The detail of the protocol is presented as follows:

Group 1: Non-anemic control, consisting of rats given $1 \mathrm{ml} / \mathrm{kg}$ of body weight / day of distilled water on D0 to D15.

Group 2: Anemic control consisting of rats given the phenylhydrazine at $40 \mathrm{mg} / \mathrm{kg} /$ day for two days (D0 and D1) and $1 \mathrm{ml} / \mathrm{kg}$ of body weight / day of distilled water from D2 to D15.

Group 3: Control reference, made of rats given the phenylhydrazine at $40 \mathrm{mg} / \mathrm{kg} /$ day for two days (D0 and D1) 
and $1 \mathrm{ml} / \mathrm{kg}$ / day of Vitafer, from D2 to D15.

Group 4: Test 1, made of rats given the phenylhydrazine at $40 \mathrm{mg} / \mathrm{kg} /$ day for two days (D0 and D1) and 100 $\mathrm{mg} / \mathrm{kg} /$ day of the Justicia galeopsis aqueous extract cooked during $30 \mathrm{~min}$ from D2 to D15.

Group 5: Test 2, made of rats given the phenylhydrazine at $40 \mathrm{mg} / \mathrm{kg} /$ day for two days (D0 and D1) and $30 \mathrm{mg}$ $/ \mathrm{kg}$ /day of the Justicia galeopsis aqueous extract cooked during $45 \mathrm{~min}$ from D2 to D15.

The administration of the extracts had begun at D2 (the third day after induction) after ascertainment of the anemia.

\subsection{Induction of Anemic Condition}

Anemia was induced by phenylhydrazine Chloridrate. Phenylhydrazine was previously dissolved in sterilized normal saline. It was administered to rats intraperitoneally (IP) at a dose of $40 \mathrm{mg} / \mathrm{kg}$ of body weight / day (Naughton al., 1995) for two days (D0 and D1). Rats that were observed to have hemoglobin levels less than 11 $\mathrm{g} / \mathrm{dL}$ were considered anemic.

\subsection{Collection and Preparation of Blood Samples}

Blood was collected early in the morning thanks to the technique of amputation of the tail tip $(5 \mathrm{~mm}$ from the end), previously disinfected with the alcohol $96{ }^{\circ} \mathrm{C}$ (Kraus, 1980). Blood was stored in the EDTA (Ethylene-Diamine-Tetra-Acetic acid) tubes for the determination of red blood cell count, hemoglobin and hematocrit. Blood samples were taken on days D0, D2, D7 and D15, the morning after the weighing.

\subsection{Evaluation of Hematological Parameters}

The hematological parameters included hemoglobin $(\mathrm{Hb})$, red blood cells (RBC) and hematocrit were determined using the automatic analyzer URIT- $2900^{\circledR}$ (Guilin, China).

\subsection{Determination of Body Absolute Organ Weights}

The body weight of each rat was assessed during the acclimatization period, once before beginning of experience, during the test period (D0, D2, D7, and D15) and on the day of sacrifice. On the day of sacrifice, all the animals were euthanized using diethyl ether in a desiccator. Different organs including the heart, liver, spleen, and kidney were carefully dissected out and weighed.

\subsection{Statistical Analysis}

Statistical tests of hematological parameters were carried out using software R. The results were expressed in the form of mean \pm standard deviation. The statistical significance of the differences between the experimental groups is determined by the Paired $t$ test. Results of the organs are presented as the average \pm standard deviation, and the differences among test groups were assessed by one-way analysis of variance followed by Duncan's New Multiple Range Test using Statistica 7.1 (StatSoft).

\section{Results}

\subsection{Effects of Justicia Galeopsis Leaves Aqueous Extract on Red Blood Cells Number}

Table 1 shows the effects of oral administration of aqueous extract of Justicia galeopsis leaves cooked during 30 and $45 \mathrm{~min}$ on red blood cells number. The administration of phenylhydrazine had caused on day D2 a significant reduction $(\mathrm{p}<0.05)$ in the red blood cells level in the rats of the four groups $(2 ; 3 ; 4$ and 5$)$ by about -20.71 to $-48.08 \%$. After treatment with $100 \mathrm{mg} / \mathrm{kg}$ of Justicia galeopsis aqueous extract cooked during $30 \mathrm{~min}$ (extract 1), a gradual recovery was obtained on the following days (+ $10.91 \%$ on D7 and $+94.94 \%$ on D15). On the other hand, in anemic rats that received distilled water, Vitafer and $30 \mathrm{mg} / \mathrm{kg}$ of Justicia galeopsis aqueous extract cooked during $45 \mathrm{~min}$ (extract 2), there was an increase in the number of red blood cells only on day 15 with a recovery rate of respectively $55 \%,+64.69 \%$ and $+60.52 \%$. The results had showed that extract 1 promotes better recovery than Vitafer, which had a higher recovery rate than extract 2 . 
Table 1. Effects of Oral Administration of Aqueous Extract of Justicia Galeopsis Leaves Cooked during 30 and 45 Min on Red Blood Cells Number

\begin{tabular}{lllll}
\hline Groups & \multicolumn{3}{l}{ Red blood cells $\left(10^{6} / \mu \mathrm{l}\right)$} \\
\cline { 2 - 5 } & $\mathrm{D} 0$ & $\mathrm{D} 2$ & $\mathrm{D} 7$ & $\mathrm{D} 15$ \\
\hline Group 1 (Control) & $5.00 \pm 2.12$ & $4.50 \pm 2.48$ & $2.92 \pm 1.70$ & $5.36 \pm 1.50$ \\
Group 2 (Positive control) & $5.12 \pm 1.77$ & $3.10 \pm 1.11$ & $2.72 \pm 1.00$ & $4.81 \pm 1.10$ \\
Variation & & $-39.45 \%^{\mathrm{a}^{*}}$ & $-120.25 \%^{\mathrm{b}}$ & $+55.16 \%^{\mathrm{b}^{*}}$ \\
Group 3 (+1 ml/kg of Vitafer) & $6.34 \pm 1.85$ & $3.51 \pm 1.40$ & $1.73 \pm 0.89$ & $5.78 \pm 1.32$ \\
Variation & & $-44.64 \%^{\mathrm{a}^{*}}$ & $-50.71 \%^{\mathrm{b}^{*}}$ & $+64.67 \%^{\mathrm{b}^{*}}$ \\
Group 4 (+100 mg/kg of extract 1) & $4.95 \pm 1.88$ & $2.57 \pm 0.93$ & $2.85 \pm 0.74$ & $5.01 \pm 1.27$ \\
Variation & & $-48.08 \%^{\mathrm{a}^{*}}$ & $+108.9 \%^{\mathrm{b}}$ & $+94.94 \%^{\mathrm{b}^{* *}}$ \\
Group 5 (+30 mg/kg of extract 2) & $4.25 \pm 2.33$ & $3.37 \pm 0.86$ & $2.19 \pm 1.07$ & $5.40 \pm 1.20$ \\
Variation & & $-20.71 \%^{\mathrm{a}}$ & $-35.01 \%^{\mathrm{b}^{*}}$ & $+60.23 \% \mathrm{~b}^{\mathrm{b}^{* *}}$ \\
\hline
\end{tabular}

${ }^{a}$ Variation percentage from day D0; ${ }^{b}$ Variation percentage from day D2; *Significant difference $(\mathrm{p}<0.05$; **Highly significant difference ( $<0.01$ ); extract 1: Justicia galeopsis aqueous extract cooked during 30 min; extract 2: Justicia galeopsis aqueous extract cooked during $45 \mathrm{~min}$

\subsection{Effects of Justicia Galeopsis Leaves Aqueous Extract on Hemoglobin Rate}

Table 2 shows the effects of oral administration of aqueous extract of Justicia galeopsis leaves cooked during 30 and $45 \mathrm{~min}$ on hemoglobin rate. The administration of phenylhydrazine had caused on day D2 a significant reduction $(\mathrm{p}<0.05)$ in the hemoglogin level in the rats of the four groups $(2 ; 3 ; 4$ and 5$)$ by about $-27.56 \%$ to $-58.77 \%$ After treatment with distilled water, Vitafer, $30 \mathrm{mg} / \mathrm{kg}$ of Justicia galeopsis aqueous extract cooked during $45 \mathrm{~min}$ (extract 2) and $100 \mathrm{mg} / \mathrm{kg}$ of Justicia galeopsis aqueous extract cooked during $30 \mathrm{~min}$ (extract 1), a gradual recovery was obtained on the following days (D7 and D15). The results had showed that after 15 days of treatment, the reduction in the hemoglobin level was completely corrected in the rats which received Vitafer and those which received the extract of leaves cooked for $30 \mathrm{~min}$, with a recovery rate greater than $100 \%$. However, the recovery rate of extract 1 is better than that of Vitafer.

Table 2. Effects of Oral Administration of Aqueous Extract of Justicia Galeopsis Leaves Cooked during 30 and 45 Min on Red Blood Cells Number on Hemoglobin Rate

\begin{tabular}{|c|c|c|c|c|}
\hline \multirow[t]{2}{*}{ Groups } & \multicolumn{4}{|c|}{ Hemoglobin rate $(\mathrm{g} / \mathrm{dl})$} \\
\hline & D0 & D2 & D7 & D15 \\
\hline Group 1 (Control) & $11.57 \pm 2.47$ & $9.08 \pm 3.23$ & $8.05 \pm 2.62$ & $13.23 \pm 1.64$ \\
\hline Group 2 (Positive control) & $11.81 \pm 2.09$ & $7.55 \pm 1.99$ & $8.65 \pm 1.32$ & $13.17 \pm 1.98$ \\
\hline Variation & & $-36.07 \%{ }^{\mathrm{a}^{* *}}$ & $+14.57 \%{ }^{b}$ & $+74.44 \% \mathrm{~b}^{\mathrm{b} * * *}$ \\
\hline Group $3(+1 \mathrm{ml} / \mathrm{kg}$ of Vitafer $)$ & $11.00 \pm 3.14$ & $7.06 \pm 2.69$ & $7.54 \pm 2.45$ & $14.45 \pm 2.12$ \\
\hline Variation & & $-35.82 \%{ }^{a^{*}}$ & $+6.80 \% \mathrm{~b}$ & $+104.67 \% \mathrm{~b}^{\mathrm{b} * * *}$ \\
\hline Group $4(+100 \mathrm{mg} / \mathrm{kg}$ of extract 1$)$ & $13.05 \pm 2.66$ & $5.38 \pm 1.73$ & $7.63 \pm 2.10$ & $13.97 \pm 1.20$ \\
\hline Variation & & $-58.77 \% \mathrm{a}^{\mathrm{*}^{* * * *}}$ & $+41.82 \% \mathrm{~b}$ & $+159.67 \% \mathrm{~b}^{* * *}$ \\
\hline Group $5(+30 \mathrm{mg} / \mathrm{kg}$ of extract 2$)$ & $9.65 \pm 2.23$ & $6.99 \pm 1.60$ & $8.65 \pm 2.30$ & $13.05 \pm 1.15$ \\
\hline Variation & & $-27.56 \% \mathrm{a}^{\mathrm{a}^{*}}$ & $+23.75 \% \mathrm{~b}$ & $+86.70 \% \mathrm{~b}^{\mathrm{b}^{* * *}}$ \\
\hline
\end{tabular}

${ }^{a}$ Variation percentage from day D0; ${ }^{b}$ Variation percentage from day D2; ${ }^{*}$ Significant difference $(\mathrm{p}<0.05$; **Highly significant difference $(\mathrm{p}<0.01) ;{ }^{* * *}$ Very highly significant difference $(\mathrm{p}<0.001)$; extract 1 : Justicia galeopsis aqueous extract cooked during $30 \mathrm{~min}$; extract 2: Justicia galeopsis aqueous extract cooked during 45 $\min$

\subsection{Effects of Justicia Galeopsis Leaves Aqueous Extract on Hematocrit Rate}

The effects of oral administration of aqueous extract of Justicia galeopsis leaves cooked during 30 and 45 min on hematocrit rate are presented in the table 3. The administration of phenylhydrazine had caused on day D2 a significant reduction $(\mathrm{p}<0.05)$ in the hematocrit level in the rats of the four groups $(2 ; 3 ; 4$ and 5$)$ by about $-21.33 \%$ to $-47.90 \%$.

After treatment with $100 \mathrm{mg} / \mathrm{kg}$ of extract of Justicia galeopsis leaves cooked during $30 \mathrm{~min}$ (extract 1), a gradual recovery was obtained on the following days $+27.53 \%$ on D7 and $+117.66 \%$ on D15). In anemic rats that had received distilled water, Vitafer and $30 \mathrm{mg} / \mathrm{kg}$ of Justicia galeopsis aqueous extract cooked during 45 
min (extract 2), there was an increase in the level of hematocrit only on day 15 with a recovery rate of respectively $+68.40 \%,+81.74 \%$ and $+84.64 \%$.

The reduction in the hematocrit level was completely corrected only in the rats which received the extract of leaves cooked for $30 \mathrm{~min}$, with a recovery rate greater than $100 \%(+117.66 \%)$. The recovery rate obtained with the extract is higher than that of Vitafer. The results had showed that extract 1 promotes better recovery than Vitafer. The recovery rate of extract $2(84.64 \%)$ is higher than that of Vitafer $(81.74 \%)$.

Table 3. Effects of Oral Administration of Aqueous Extract of Justicia Galeopsis Leaves Cooked during 30 and 45 Min on Red Blood Cells Number on Hematocrit Rate

\begin{tabular}{lllll}
\hline Groups & \multicolumn{3}{l}{ Hematocrit rate $(\%)$} & \\
\cline { 2 - 5 } & $\mathrm{D} 0$ & $\mathrm{D} 2$ & $\mathrm{D} 7$ & $\mathrm{D} 15$ \\
\hline Group 1 (Control) & $32.50 \pm 12.63$ & $26.82 \pm 14.83$ & $17.02 \pm 9.75$ & $34.31 \pm 6.66$ \\
Group 2 (Positive control) & $32.03 \pm 9.46$ & $20.03 \pm 5.76$ & $20.02 \pm 7.97$ & $33.73 \pm 6.32$ \\
Variation & & $-37.45 \%^{\mathrm{a}^{*}}$ & $-0.08 \%^{\mathrm{b}}$ & $+68.36 \%^{\mathrm{b}^{* *}}$ \\
Group 3 (+ 1 ml/kg of Vitafer) & $34.12 \pm 13.97$ & $20.48 \pm 8.37$ & $13.16 \pm 7.47$ & $37.22 \pm 10.02$ \\
Variation & & $-39.98 \%^{\mathrm{a}}$ & $-3574 \%^{\mathrm{b}}$ & $+8174 \%^{\mathrm{b}^{*}}$ \\
Group 4 (+ 100 mg/kg of extract 1) & $29.98 \pm 9.41$ & $15.62 \pm 5.55$ & $19.92 \pm 3.94$ & $34.00 \pm 7.00$ \\
Variation & & $-47.90 \%^{\mathrm{a}^{* *}}$ & $+27.53 \% \%^{\mathrm{b}}$ & $+117.66 \%^{\mathrm{b}^{* * *}}$ \\
Group 5 (+ 30 mg/kg of extract 2) & $24.66 \pm 9.26$ & $19.40 \pm 4.86$ & $16.25 \pm 8.89$ & $35.82 \pm 8.89$ \\
Variation & & $-21.33 \%^{\mathrm{a}}$ & $-16.23 \% \%^{\mathrm{b}}$ & $+84.64 \%^{\mathrm{b}^{* *}}$ \\
\hline
\end{tabular}

${ }^{\mathrm{a}}$ Variation percentage from day D0; ${ }^{\mathrm{b}}$ Variation percentage from day D2; ${ }^{*}$ Significant difference $(\mathrm{p}<0.05$; **Highly significant difference $(\mathrm{p}<0.01) ;{ }^{* * * *}$ Very highly significant difference $(\mathrm{p}<0.001)$; extract 1 : Justicia galeopsis aqueous extract cooked during $30 \mathrm{~min}$; extract 2: Justicia galeopsis aqueous extract cooked during 45 $\min$

\subsection{Effects of Justicia Galeopsis Leaves Aqueous Extract on Liver, Spleen, and Kidney}

As depicted in tables 4, oral administration of $100 \mathrm{mg} / \mathrm{kg}$ body weight of extract 1 (aqueous extract of Justicia galeopsis leaves cooked during $30 \mathrm{~min}$ ) and $30 \mathrm{mg} / \mathrm{kg}$ body weight of extract 2 (aqueous extract of J. galeopsis leaves cooked during $30 \mathrm{~min}$ ) in rats at a dose of daily had no significant effect on liver and kidney weights. However, the spleen weight was significantly greater in the anemic rats untreated and treated with Vitafer and the extracts of J. galeopsis leaves when compared to the non-anemic group.

Table 4 Effects of Oral Administration of Aqueous Extract of Justicia Galeopsis Leaves Cooked during 30 and 45 Min on Organ Weights

\begin{tabular}{llll}
\hline Groups & \multicolumn{2}{l}{ Organ weights $(\mathrm{g})$} \\
\cline { 2 - 4 } & Liver & Spleen & Kidney \\
\hline Group 1 (Control) & $0.79 \pm 0.13^{\mathrm{a}}$ & $0.37 \pm 0.14^{\mathrm{a}}$ & $4.11 \pm 0.40^{\mathrm{a}}$ \\
Group 2 (Positive control) & $0.79 \pm 0.10^{\mathrm{a}}$ & $0.53 \pm 0.19^{\mathrm{ab}}$ & $3.97 \pm 0.65^{\mathrm{a}}$ \\
Group 3 (+ 1 ml/kg of Vitafer) & $0.83 \pm 0.11^{\mathrm{a}}$ & $0.43 \pm 0.10^{\mathrm{ab}}$ & $4.05 \pm 0.46^{\mathrm{a}}$ \\
Group 4 (+ 100 mg/kg of extract 1) & $0.87 \pm 0.15^{\mathrm{a}}$ & $0.55 \pm 0.14^{\mathrm{b}}$ & $3.80 \pm 0.62^{\mathrm{a}}$ \\
Group 5 (+30 mg/kg of extract 2) & $0.86 \pm 0.09^{\mathrm{a}}$ & $0.60 \pm 0.19^{\mathrm{b}}$ & $4.28 \pm 0.70^{\mathrm{a}}$ \\
\hline
\end{tabular}

Results are expressed as Mean \pm standard deviation (SD) for eight animals per group; means with different superscript letters in the columns are significantly different using the Student's t-test $p<0.05$ was considered statistically significant

\section{Discussion}

Subacute intoxication of rats with $40 \mathrm{mg}$ per kilogram body weight of Phenylhydrazine (PHZ) for two days resulted in decreasing of red blood cell count, hemoglobin and hematocrit values caused by hemolytic anemia. Administration of PHZ to rats has been reported to result in the production of both aryl and hydroxyl radicals which produce oxidative stress on the red cell membrane resulting in hemolysis by lipid peroxidation Cighetti et al. (1999). According to Ferrali et al. (1997) this lipid peroxidation increase methaemoglobinemia in the blood. These Similar results were reported by Tossou et al. (2008) in rats administered with PHZ to induce anemia.

The group of positive control rats (anemia rats receiving no treatment) had a recovery rate of red blood cells (+ $55 \%)$, hemoglobin $(+74.46 \%)$ and hematocrit $(+68.36 \%)$ lower than that of the other groups which also 
received PHZ. Indeed, the body had tried to correct the losses caused by the injection of PHZ but this correction was incomplete until D15. According to Nancy (2011) under normal conditions, the body generates new red blood cells to replace the lost ones but this takes longer; as observed in the untreated anemic rats. So, these rats will need a treatment favoring the increase in hematological parameters following disorders leading to their decrease.

The decrease in red blood cells was almost completely corrected $(+94.94 \%)$ in the group of rats which had received $100 \mathrm{mg} / \mathrm{kg}$ of Justicia galeopsis leaves extract cooked during $30 \mathrm{~min}$ in contrary to those which had received Vitafer $(+64.67 \%)$ and $30 \mathrm{mg} / \mathrm{kg}$ of extract $2(+60.23 \%)$. The extract of leaves cooked during $30 \mathrm{~min}$ allows a better stimulation of the synthesis of red blood cells. These results are better than those of Tossou et al. (2008) who had showed that the administration of $1000 \mathrm{mg} / \mathrm{kg}$ of Justicia secunda leaf extract increased the number of red blood cells with a recovery of $+98.11 \%$.

The decrease in hemoglobin induced by phenylhydrazine was completely corrected in the group of rats which received extract 1 and the group of those which received Vitafer. Hemoglobin is the key element in the structure of red blood cells, stimulating their synthesis will also stimulate the production of red blood cells. Therefore, massive production of hemoglobin will cause more red blood cells. Thus, the hemoglobin recovery rate of rats having received the extract of cooked leaves for $30 \mathrm{~min}$ being higher $(+159.53 \%)$ than that of rats having received Vitafer $(+104.67 \%)$, their red blood cell recovery rate will also be higher than those of rats having received Vitafer and the extract 2 as indicated by le results. The speedy and progressive recovery of anemic rats on treatment with extracts 1 could be due to increased erythropoiesis. According to Koury and Ponka (2004), Folate, vitamin B, and iron are required for optimal erythropoiesis. In fact, according to Loukou et al. (2018), Justicia galeopsis uncooked leaves are very rich in vitamin B12 $(4173.09 \mathrm{mg} / \mathrm{kg})$ and vitamin C $(892.17 \mathrm{mg} / \mathrm{kg})$. Their leaves cooked during $30 \mathrm{~min}$ contain more iron $(458.98 \mathrm{mg} / \mathrm{kg})$ and vitamin $\mathrm{C}(4.75 \pm 1.60 \mathrm{mg} / 100 \mathrm{~g})$ than the leaves cooked during $45 \mathrm{~min}$ which contain $453.93 \mathrm{mg} / \mathrm{kg}$ of iron and $3.80 \mathrm{mg} / 100 \mathrm{~g}$ of vitamin C (Loukou et al., 2020). This composition of Justicia galeopsis leaves extract cooked during 30 min may account for the faster reversal of PHZ induced anemia.

The decrease in hematocrit level observed was completely corrected in rats which received the extract of leave cooked during $30 \mathrm{~min}$. The hematocrit corresponds to the volume occupied by red blood cells in the blood volume, its value depends on the number of red blood cells in the blood volume. However, this explains the fact that the hematocrit recovery rate of rats having received the extract of the leaves cooked during $30 \mathrm{~min}$ is higher than that of the other groups of rats because of its highest recovery rate of red blood cells. This result is better than that observed by Tossou et al. (2008) with the administration of $1000 \mathrm{mg} / \mathrm{kg} / \mathrm{day}$ of extract of Justicia secunda leaves in Benin.

There was no significant difference in the liver and kidney weight for all groups relative to the non-anemic, anemic control and treated with Vitafer and J. galeopsis extracts. This indicates that the extracts of J. galeopsis leaves were not toxic for those organs at the doses administered. The relative spleen weight was significantly greater in the anemic control and anemic rats untreated and treated when compared to the non-anemic group. This effect is mainly the consequence of the metabolism of phenylhydrazine, as had been suggested earlier. The spleen serves to cleanse the body of damaged old particles transported by the blood (Australasian Society of Clinical Immunology and Allergy 2014). This suggests that an increase in the relative spleen weight might be attributed to the spleen fighting foreign particles due to the anemic condition of the rats. This is also consistent with authors who suggested that the rate of erythropoiesis and 2'5'-A polymerase activity increases after a dose of phenylhydrazine (Orlic et al., 1982).

\section{Conclusion}

In conclusion, the in vivo study had confirmed the hematinic activity of aqueous extract of Justicia galeopsis leaves cooked during 30 and $45 \mathrm{~min}$. The administration of $100 \mathrm{mg} / \mathrm{kg} /$ day of extract of leaves cooked during 30 min promotes a better recovery rate of the number of red blood cells $(94.80 \%)$, hemoglobin level $(159.53 \%)$ and hematocrit $(117.72 \%)$ than Vitafer and the extract of leaves cooked for $45 \mathrm{~min}$. The leaves of Justicia galeopsis therefore have anti-anemic properties. Therefore, this plant could be used in the management and the treatment of anemia.

\section{Acknowledgments}

The authors thank technician of the national floristic center Mr. Yapo ASSI Jean for authentication and identification of Justicia galeopsis leaf, Hanzi Kerene KOUAME for its assistance in samples lyophilization and Guillaume DROUCOULA for its help in Phenyl hydrazine Chloride acquisition. 


\section{References}

Afolabi, I., Sunmola, A. O. N., Fashola, D. V., \& Famakin, T. C. (2012). Comparative evaluation of the nutritional benefits of some underutilized plants leaves. Journal of Natural Product and Plant Resources, 2(2), 261-266. Retrieved from https://www.scholarsresearchlibrary.com/articles/comparative-evaluation-of-the-nutritional-benefits-of-som e-underutilisedplants-leaves.pdf

Agbemafle, R., Obodai, E. A., Adukpo, G. E., \& Amprako, D. N. (2012). Effects of boiling time on the concentrations of vitamin $\mathrm{c}$ and beta-carotene in five selected green vegetables consumed in Ghana. Advances in Applied Science Research, 3(5), 2815-2820. Retrieved from https://www.imedpub.com/articles/effects-of-boiling-time-on-the-concentrations-of-vitamin-c-and-betacarot ene-infive-selected-green-vegetables-consumed-in-ghana.pdf

Aka, N., Bamba, S. B., Soro, G., \& Soro, N. (2013). Etude hydrochimique et microbiologique des nappes d'altérites sous climat tropical humide: cas du département d'Abengourou (Sud-Est de la Côte d'Ivoire). Larhyss Journal, 16, 31-52. Retrieved from http://archives.univ-biskra.dz/bitstream/123456789/64/1/3.Aka_et_al.pdf

Australasian Society of Clinical Immunology and Allergy (2014, March 30). Immune system explained. Better health channel, pp. A4.

Cighetti, G., Debiasis, S., Paroni, R., \& Allevi, P. (1999). Free and total malondialdehyde assessment in biological matrices by GC/MS What is needed for an accurate detection? Analytical Chemistry, 266, 222-229. https://doi.org/10.1006/abio.1998.2952

Ferrali, M., Signorini, C., Sugherini, P., Lodovic, A., Caciotti, B., Ciccoli, L., \& Comporti, M. (1997). Release of free redox-active iron in the liver and DNA oxidative damage following Phenylhydrazine intoxication. Biochemical Pharmacology, 53, 1743-1751. https://doi.org/10.1016/S0006-2952(97)82456-2

Green, R. (2017). Vitamin B12 deficiency from the perspective of a practicing hematologist. Blood, 129(19), 2603-2611. https://doi.org/10.1182/blood-2016-10-569186

Idu, M.-D., Igbafe, G., \& Erhabor J. (2014). Anti-anaemic activity of Jatropha tanjorensis Ellis \& Saroja in Rabbits. Journal of Medicinal Plants Studies, 2(1), 64-72. Retrieved from http://www.plantsjournal.com/archives/2014/vol2issue1/PartA/11.1.pdf

Kouakou, K. H. (2015). Etude de consommation et valeur nutritionnelle d'une plante spontanée, Solenostemon monstachyus (P Beauv) Briq, dans le département d'Abengourou (Mémoire de master non publié). Université Nangui Abrogoua, Abidjan, Côte d'Ivoire.

Koury, M. J., Ponka, P. (2004). New insights into erythropoiesis: The Roles of Folate, Vitamin B12, and Iron. Annual Review of Nutrition, 24, 105-31. https://doi.org/10.1146/annurev.nutr.24.012003.132306

Kraus, A. L. (1980). Research methodology. In H. J. Baker, J. R. Lindsey \& S. R. Weisbroth (Eds.), The Laboratory Rat Vol 2: Research applications (pp. 19-23). New York, NY: Academic Press.

Loukou, A. L., Anvoh, K. Y. B., Kouakou, K. H., \& Brou, K. (2018). Nutritional composition and bioavailability prediction calcium, iron, zinc and magnesium in Justicia galeopsis leaves in Côte d'Ivoire. International Journal of Biological and Chemical Sciences, 12(6), 2615-2625. https://dx.doi.org/10.4314/ijbcs.v12i6.12

Luka, C. D., Abdulkarim, M., Adoga, G. I., Tijjani, H., \& Olatunde, A. (2014). Antianaemic potential of aqueous extract of Spinacia oleracea leaf in phenylhydrazine-treated rats. New York Science Journal, 7(6), 14-18. Retrieved from http://www.sciencepub.net/newyork/ny0706/003_24862ny070614_14_18.pdf

Madukwe, E. U., Ugwuoke, A. L., \& Ezeugwu, J. O. (2013). Effectiveness of dry Moringa oleifera leaf powder in treatment of anemia. International Journal of Medicine and Medical Sciences, 5(5), 226-228. Retrieved from https://academicjournals.org/journal/IJMMS/article-full-text-pdf/86F279D77

McLean, E., Cogswell, M., Egli, I., Wojdyla, D., \& Bruno de Benoist, (2008). Worldwide prevalence of anaemia, WHO Vitamin and Mineral Nutrition Information System, 1993-2005. Public Health Nutrition, 12(4), 444-454. https://doi.org/10.1017/S1368980008002401

Nancy, L. C. (2011). Nancy Caroline's Emergency Care in the Streets (Canadian Edition 6th ed.), Canada, Mississauga: Jones \& Bartlett Publishers.

Naughton, B. A., Moore, E., Bush, M. E., Lapin, D. M., \& Dornfest, B. S. (1995). Hemostatic alterations associated with phenylhydrazine induced haemolytic anaemia. European Journal of Clinical Investigation, 


\section{5, 722-7. https://doi.org/10.1111/j.1365-2362.1995.tb01950.x}

Obichi, E. A., Monago, C. C., \& Belonwu, D. C. (2015). Nutritional Qualities and Phytochemical Compositions of Solenostemon monostachyus (Family Lamiaceae). Journal of environment and earth science, 5(3), 105-111. Retrieved from https://www.semanticscholar.org/paper/Nutritional-Qualities-and-Phytochemical-of-(Family-Obichi-Monag o/83de4dcbffb366ce0b7c7dd207f873ab664dfabe

Orlic, D., Wu, J. M., Carmichael, R. D., Quaini, F., Kobylack, M., \& Gordon, A. S. (1982). Increased erythropoiesis and 2'5'-A polymerase activity in the marrow and spleen of phenylhydrazine-injected rats. Experimental Hematology, 10(5), 478-485. Retrieved from https://europepmc.org/article/med/6284534

Osime, E. O., Ediale, G. E., Omoti, C. E., \& Famodu, A. A. (2008). Effect of sweet potato leaf (Ipomoea batatas) extract on some haematological parameters using rabbits. Journal of Biomedical Science, 7(1\&2), 5-11. https://doi.org/10.4314/jmbr.v7i1-2.44540.

Ponmozhi, E., \& Ramya, B. (2015). Anti-anemic activity murraya koenigii leaves on phenylhydrazine Induced anemia in rats. World Journal of Science and Research, 1(1), 1-8. Retrieved from http://www.harmanpublications.com

Ramakrishnan, U. (2002). Prevalence of micronutrient malnutrition worldwide. Nutrition Reviews, 40, 46-52. https://doi.org/10.1301/00296640260130731

Randrianatoandro, V. A. (2010). Identification et caractérisation des plats sources en micronutriments consommés en milieu urbain (Manjakaray, Madagascar) : étude des plats à base de légumes-feuilles (Thèse de doctorat non publiée). Université d'Antananarivo, Antananarivo, Madagascar.

Séguéna, F., Soro, K., Soro, D., \& N'guessan, K. (2013). Savoir-faire de populations locales des taxons du jardin Botanique de Bingerville, Côte d'Ivoire. Journal of Applied Biosciences, 68, 5374-5393. https://doi.org/10.4314/jab.v68i0.95064

Sènou, M., Tchogou, A. P., Dougnon, T. V., Agossadou, A., Assogba, F., Kinsiclounon, E. G., ... Loko, F. (2016). Efficiency of Sorghum bicolor extract in the treatment of induced anemia on Wistar rats. International Journal of Biosciences, 8(4), 62-71. http://dx.doi.org/10.12692/ijb/8.4.62-71

Tossou, R., Gbenou, J. O., Dansou, P., Fossou, M., \& Moudachirou, M. (2008). Etude des propriétés antianémiques de Justicia secundo Vahl (Acanthaceae) chez des rats de souche Wistar. Revue Cames, 6, 26-29. Retrieved from http://greenstone.lecames.org/collect/revu/index/assoc/HASH6949.dir/A-006-00-026-029.pdf

\section{Copyrights}

Copyright for this article is retained by the author(s), with first publication rights granted to the journal.

This is an open-access article distributed under the terms and conditions of the Creative Commons Attribution license (http://creativecommons.org/licenses/by/4.0/). 